\section{Soil Moisture Response To Range Improvement In The Northern Great Plains}

\author{
Walter R. Houston
}

Research Range Conservationist, Crops Research Division, Agricultural Research Service, USDA, Miles City, Montana. ${ }^{1}$

An understanding of soil moisture regimes and the factors which influence them is basic to improving range productivity in the West. Moisture is no doubt the most important single influence affecting range forage production in the largely semi-arid climate. Soil types, grazing systems, and range improvement practices are important influences on range forage production, composition, and quality. Other factors such as soil aeration, toxic soil materials, and topography are occasionally important, but usually locally. Many of these factors are interrelated in their effects, but commonly moisture is limiting.

1 Cooperating with Montana Agricultural Experiment Station and Animal Husbandry Research Division.
The results of an investigation into the influences of range pitting, fertilization, and protection from grazing on soil moisture (as moisture potential or soil moisture stress) in a low rainfall area of the Northern Great Plains, are reported here. Also studied were the effects and interactions of precipitation, soils, and livestock grazing rates. Relationships between soil moisture potential and various components of herbage production, and the influences and interactions of the main factors on these relationships were included.

Range pitting has been shown generally to improve forage production. It is believed this influence is manifested through reduction of surface run-off and moisture accumulation in the basins formed (Barnes, 1952; Rauzi and Lang, 1956; Thomas and Young, 1956), and by increased infiltration into the soil (Barnes, 1952; Lang, 1958). The possible effect on soil moisture from the reduction of plant cover accompanying pitting is little known.

Nitrogen fertilization of rangeland has been found by several investigators to increase forage production and protein content of herbage (Rogler and Lorenz, 1957; Smika et al. 1960), but the increase was not always profitable. Nitrogen also has caused earlier maturity of vegetation and earlier and greater depletion of soil moisture (McKell et al., 1959; Sneva et al., 1958).

The effects of heavy livestock grazing (a combination of excessive forage utilization and livestock trampling) in reducing forage production have been shown by many investigators (Johnson, 1953; Klipple and Costello, 1960; Reed and Peterson, 1961). Some have indicated that heavy grazing reduced soil moisture infiltration rates and accumulation (Klipple and Costello, 1960; Rauzi and Kuhlman, 1961; Reed and Peterson, 1961).

Clipping vegetation at various intervals and heights to simulate different stocking levels has influenced production, forage quality, and soil moisture regimes and depletion curves (Baker and Hunt, 1961; Blaisdell and Pechanec, 1949; McKell et al., 1960).

The influence of soil types on soil moisture is well known. Fine textured soils usually accumulate a greater quantity of moisture than coarse textured ones, and they also retain a greater amount at plant wilting (Thorne and Raney, 1956). However, precipitation generally wets sandy soils to greater depths 
than clayey soils. Richards and Marsh (1961) point out that soil suction (soil moisture stress or potential) is a property of the film of water around soil particles, and that for this property stress readings have the same meaning independent of soil type.

\section{Method of Study}

The study was established on native range near Miles City, Montana in October 1958. Gypsum soil moisture blocks were placed in duplicate on 4 rangeland treatments at each of 12 locations ( 6 soils $\times 2$ stocking rates). The blocks were rectangular with parallel screen electrodes. They were constructed of plaster-of-paris by the Utah Agriculture Experiment Station as suggested by Taylor et al., (1961) and selected for uniformity. Blocks were placed at 4 depths (6, 18,30 , and 42 inches). Range improvement treatments were: 1), normal grazing (control); 2), protection or rest from grazing; 3 ), range pitting with offset disc; and 4), 30 pounds of nitrogen as ammonium nitrate applied in 1958 only. The control treatment remained open to grazing while the remaining ones were fenced after establishment.

Stocking levels were maintained since 1932 except in 1936-7 and 1946 when no grazing was permitted. Average stocking rate for the heavily grazed pastures was about 1.9 acres per animal-unit-month and the lightly grazed pastures 3.3 acres. Actual stocking levels on the small study areas were unknown.

The soils were identified by Gieseker (1948) as follows: Soil 1; level, heavy stream wash, overflow range site. Soil 2; Fort Collins fine sandy loam, 3-4 percent slope to north and northwest, silty range site. Soil 3; Grail silty clay loam, 6 percent slope to northwest, clayey range site. Soil 4; Beckton silty clay loam, 1-2 percent slope to east and southeast, (slick spots) dense clay range site. Soil 5; Moline clay loam, 8-10 percent slope to south, pan spots range site. Soil 6; unnamed clay loam, 2 percent slope to northeast, pan spots range site.

Beginning in early April 1959 periodic determinations of soil water potential or total soil moisture stress were made in terms of block electrical resistance. The determinations were repeated at approximately

Table 1. Monthly and total annual precipitation in inches, 1958-61 and 84year average, U. S. Range Livestock Exporiment Station near Miles City, Montana.

Jan.

\begin{tabular}{rrrrrrrrrrrrrr}
\hline 1958 & .31 & .58 & .60 & 1.21 & .16 & 2.27 & 3.17 & .49 & .18 & 1.58 & 1.31 & .73 & 12.59 \\
1959 & .84 & .77 & .11 & .97 & 1.76 & 1.78 & .39 & .89 & 1.51 & .64 & .61 & .07 & 10.34 \\
1960 & .43 & .43 & .83 & .79 & 1.29 & 1.75 & .53 & 1.01 & .00 & .27 & .22 & .53 & 8.08 \\
1961 & .07 & .63 & .32 & 1.17 & 2.41 & .80 & .68 & .94 & 2.53 & .14 & .77 & .23 & 10.69
\end{tabular}

84-year average, $1877-1961$

$\begin{array}{lllllllllllll}.55 & .45 & .76 & 1.04 & 1.97 & 2.65 & 1.47 & 1.11 & .99 & .85 & .51 & .47 & 12.82\end{array}$

three week intervals through October. Observations were also made in 1961 for the same period and at about the same intervals.

Herbage production was determined from ten $1 \times 2$-feet clipped plots at each site in mid-summer each year.

The electrical resistance measurements are directly related to water potential (see figure 1, McKell et al., 1959) and inversely related to moisture availability for plant growth. A high resistance value denotes high soil moisture stress and low moisture availability. The resistance measurements are on a logrithmic scale. The logarithms of the resistance values (base 10) were used in all data analyses. All tabular means of resistances are conversions from logarithmic means.

Precipitation, as recorded about 4 miles northwest of the study area, was below average during 1959, 1960, and 1961 (table 1). Severe drought effects on vegetation were experienced in 1961; an apparent cumulative effect of the series of dry years. Total annual precipitation during 1958 was about normal except that a large portion of the moisture occurred during July and the fallwinter months of October-December. Because of the above-average precipitation during these months it is believed that soil moisture at the beginning of plant growth in 1959 was near average.

\section{Soil Moisture}

Treatment Effects.-The influence of range improvement treatments on soil water potential or moisture stress was significant in both years (table 2$)^{2}$. The highest average

2 Several investigators have indicated block resistance of 200-800 ohms as field capacity and 60,00075,000 ohms as the lower limit of an average plant wilting range (Chamblee, 1958). stress (or lowest moisture availability) was on the control treatment and the lowest on the pitted treatment. The rest from grazing and the fertilizer treatments were at intermediate levels in both years. Average moisture stress on each treatment in 1961 was about double that of 1959. The yearly differences reflect a direct response of soil moisture to the amount of rainfall during the current spring-early summer and the previous late summer and fall.

The treatment differences indicate that range pitting effectively reduces soil moisture stress in the soil profile even during drought. This is probably due to reduction of run-off and accumulation of moisture and increased infiltration in the pits. Protection from grazing reduced average soil moisture stress in 1961, in the third year of study. No significant reduction was evident the first year on this treatment.

Soil Effects and Interaction.-The effects of treatments on soil moisture were different between soils (table 3 ). Pitting greatly reduced average soil moisture stress on both soils 5

Table 2. Comparison of treatment effects on average soil moisture stress as electrical resistance in 1959 and 1961.1

\begin{tabular}{llcc}
$\begin{array}{l}\text { Treat } \\
\text { ment }\end{array}$ & 1959 & 1961 & Average \\
\hline \multicolumn{4}{c}{ Ohms (x100) } \\
Control & $41.4 a$ & $83.2 a$ & 58.7 \\
Rest & $31.2 a$ & $58.5 b$ & 42.8 \\
Pitted & $22.8 b$ & $40.3 c$ & 30.3 \\
30\#N & $32.2 a$ & $68.6 a b$ & 47.0 \\
Average & 31.4 & 60.5 &
\end{tabular}

1 Each mean is a conversion from the logarithmic mean resistance over six soils, two stocking rates, and four soil depths. Means in the same column followed by the same letter are not significantly different at the 5 percent level (Duncan, 1955). 
Table 3. Comparison of treatment effects on soil moisture stress by soils and years. ${ }^{1}$

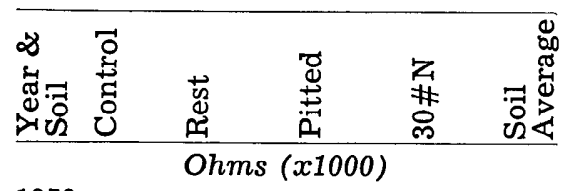

1959

$\begin{array}{llllll}1 & 10 a & 7 a & 14 a & 8 a & 9 e\end{array}$

$\begin{array}{llllll}2 & 11 b & 38 a & 17 a b & 33 a & 22 d\end{array}$

$3 \quad 180 a \quad 115 a b \quad 137 a b \quad 71 b \quad 119 a$

$\begin{array}{llllll}4 & 47 a & 22 a & 53 a & 36 a & 38 c\end{array}$

$\begin{array}{llllll}5 & 115 a & 76 a b & 31 b & 69 a b & 66 b\end{array}$

$\begin{array}{llllll}6 & 47 a & 18 b & 3 c & 24 a b & 15 d\end{array}$

1961

$1 \quad 52 a \quad 25 b \quad 34 a b \quad 50 a$

$\begin{array}{lllll}2 & 133 a & 99 a & 106 a & 113 a\end{array}$

$\begin{array}{lllll}3 & 171 a & 243 a & 181 a & 251 a\end{array}$

$\begin{array}{lllll}4 & 58 a & 39 a & 38 a & 42 a\end{array}$

$\begin{array}{lllll}5 & 108 a & 81 a & 33 b & 73 a\end{array}$

$\begin{array}{llllll}6 & 45 a & 21 b & 5 c & 24 b & 19 e\end{array}$

1 Each mean is a conversion from the logarithmic mean resistance over two stocking rates and four soil depths. Means in the same row across treatments or the same column of averages within years followed by the same letter are not significantly different at the 5 percent level (Duncan, 1955).

(Moline clay loam) and 6 (unnamed clay loam) in both years, but had no influence on the remaining soils in either year. The rest treatment reduced moisture stress below the level of the grazed control on soil 6 in 1959, and on soil 1 (overflow-stream wash) and 6 in 1961. This treatment resulted in increased average moisture stress on soil 2 (Fort Collins fine sandy loam) in 1959. Soil moisture infiltration may have been increased by the rest treatment on soil 6 .

The application of 30 pounds per acre of nitrogen fertilizer in the fall of 1958 also resulted in reduced soil moisture stress on certain soils. Average moisture stress was reduced by the fertilizer treatment on soil 3 (Grail silty clay loam) in 1959 and on soil 6 in 1961. Moisture stress was increased on soil 2 in 1959 by this treatment. Apparently the nitrogen fertilizer treatment increased evapotranspiration loss of soil moisture on the fine sandy loam soil 2 in 1959, but resulted in decreased moisture loss or increased moisture infiltration on several of the more clayey soils. The high level of moisture stress in 1961 may have covered up

Table 4. Effects of heavy and light stocking rates on average soil moisture stress by treatments, soils, and years. ${ }^{1}$

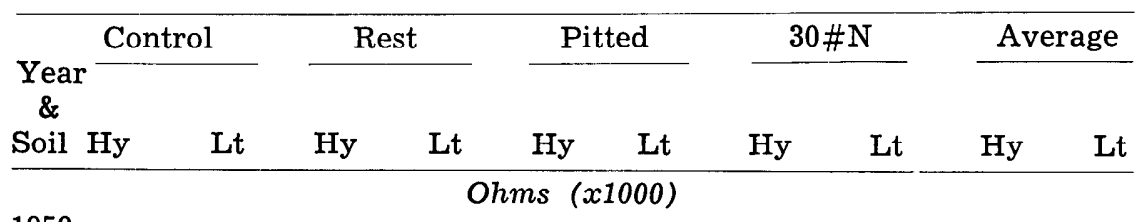

1959

\begin{tabular}{lrrrrrrrrrr}
1 & $23 a$ & $5 b$ & $9 a$ & $5 a$ & $14 a$ & $14 a$ & $16 a$ & $4 b$ & $15 a$ & $6 b$ \\
2 & $2 b$ & $64 a$ & $58 a$ & $25 a$ & $3 b$ & $115 a$ & $27 a$ & $40 a$ & $9 b$ & $52 a$ \\
3 & $169 a$ & $191 a$ & $64 a$ & $208 a$ & $177 a$ & $106 a$ & $116 a$ & $44 a$ & $122 a$ & $117 a$ \\
4 & $34 a$ & $66 a$ & $39 a$ & $12 a$ & $48 a$ & $58 a$ & $89 a$ & $15 b$ & $49 a$ & $29 a$ \\
5 & $63 a$ & $211 a$ & $21 b$ & $270 a$ & $23 a$ & $43 a$ & $27 b$ & $179 a$ & $30 b$ & $145 a$ \\
6 & $49 a$ & $45 a$ & $9 b$ & $36 a$ & $3 a$ & $2 a$ & $33 a$ & $18 a$ & $15 a$ & $15 a$ \\
Av. & $30 b$ & $57 a$ & $25 a$ & $39 a$ & $17 b$ & $34 a$ & $40 a$ & $26 a$ & $27 b$ & $37 a$ \\
1961 & & & & & & & & & \\
1 & $93 a$ & $29 b$ & $51 a$ & $12 b$ & $45 a$ & $26 a$ & $60 a$ & $41 a$ & $60 a$ & $25 b$ \\
2 & $105 a$ & $167 a$ & $124 a$ & $79 a$ & $70 a$ & $161 a$ & $102 a$ & $126 a$ & $98 a$ & $128 a$ \\
3 & $220 a$ & $133 a$ & $262 a$ & $225 a$ & $221 a$ & $148 a$ & $238 a$ & $265 a$ & $235 a$ & $185 a$ \\
4 & $68 a$ & $50 a$ & $99 a$ & $16 b$ & $39 a$ & $37 a$ & $112 a$ & $16 b$ & $74 a$ & $26 b$ \\
5 & $49 b$ & $234 a$ & $17 b$ & $388 a$ & $13 b$ & $86 a$ & $29 b$ & $186 a$ & $24 b$ & $195 a$ \\
6 & $56 a$ & $36 a$ & $15 a$ & $30 a$ & $6 a$ & $4 a$ & $25 a$ & $24 a$ & $19 a$ & $18 a$ \\
Av. $86 a$ & $80 a$ & $59 a$ & $58 a$ & $36 a$ & $45 a$ & $70 a$ & $67 a$ & $60 a$ & $61 a$ \\
\hline
\end{tabular}

1 Each mean is a conversion from the logarithmic mean over four soil depths. Means in the same treatment-soil combination within years followed by the same letter are not significantly different at the 5 percent level (Duncan, 1955).

any fertilizer insluence on average moisture stress on the remaining soils, or the fertilizer may have been used up by 1961 . It is very doubtful that any of the fertilizer was leached through the soil profile.

Stocking Rate Effects and Interactions.-Heavy and light stocking levels since 1932 significantly influenced overall, average soil moisture stress in the near normal rainfall year of 1959, but had no effect in the drought year of 1961 (table 4). In 1959 average moisture stress was lower under heavy stocking, probably due, at least in part, to some combination of lower transpiration loss from reduced root growth, plant growth, and plant vigor, and more shallow-rooted species caused by repeated close grazing of the vegetation.

Lower average moisture stress was found under heavy grazing than under light on the control and pitted treatments in 1959. On the rest and fertilizer treatments stress was similar under both stocking rates in 1959. No significant differences in stress were present between stocking levels in 1961 on any treatment.

The overall effects of past stocking levels on average soil moisture stress differed considerably between soils. On fine sandy loam soil 2 in 1959 and on clay loam soil 5 in both rears, stress was much lower on the heavily grazed areas. In contrast, on clayey overflow soil 1 in both years and on dense clay soil 4 (Beckton silty clay loam) in 1961 stress was significantly higher under heavy grazing. No differences between stocking levels were found on silty clay loam soil 3 and clay loam soil 6 in either year.

These differences between soils in the responses of soil moisture potential to stocking rates seem related to a combination of variations in texture, slope, and exposure. Soils 1 and 4 probably have higher proportions of clay than the other soils, and are essentially level. Soil 2 has a higher composition of sand than the other soils, and the experimental sites on soil 5 are on a steep southern exposure. Blue grama (Bouteloua gracilis (H.B.K.) Lag.) is a dominant species on both soils 2 and 5 . The experimental areas on soils 3 and 6 are on 2-6 percent northerly slopes. Thus, it appears that heavy grazing caused reduced soil moisture stress on a fine sandy loam soil dominated by blue grama or on a clayey soil with a southern exposure. Heavy grazing caused increased soil moisture stress on level soils with high 
clay content. Stocking levels apparently had no effect on moisture stress on clay loam or on silty clay loam soil with a northerly exposure.

The effects of heavy stocking on increasing soil moisture stress of the clayey soils 1 and 4 may be due in large part to a compacting and sealing of the soil surface from livestock trampling, thus reducing moisture infiltration and resulting in drier sub-soil. On sandy loam soil 2 and on a southern exposure of clay loam soil 5, the effects of heavy grazing may be due largely to repeated close grazing of vegetation with consequent reduced plant vigor and growth and lower transpiration use of soil moisture.

Considerable interaction effects on soil moisture stress were also present between stocking rates, soils, and treatments. On overflow soil 1, average moisture stress was significantly lower under light stocking on the control and fertilized treatments in 1959 and on the control and rest treatments in 1961. For soil 1 in 1959 , a normal moisture year, previous stocking rates resulted in a significant difference in stress on the fertilized treatment in contrast to no difference in 1961, a drought year. The opposite relationship between past stocking rates and years was observed on the rest treatment on this soil.

On fine sandy loam soil 2 , average moisture stress was lower in 1959 under heavy stocking than under light stocking on the control and pitted treatments. No differences between stocking levels were present in 1961 on any treatment on this soil.

On soil 3 (Grail silty clay loamthe driest soil examined) the influences of stocking rates on average soil moisture stress were not significant on any treatment in either year.

On dense clay soil 4 moisture stress was lower under light stocking on the fertilizer treatment in both years and on the rest treatment in 1961. In the third year after protection from grazing, soil moisture infiltration appeared improved on sites previously lightly grazed.

On clay loam soil 5 average moisture stress was lower under heavy stocking than under light stocking on the rest and fertilized treatments in 1959, but was uniformly lower under heavy stocking on all treat- ments in 1961. On clay loam soil 6 stress was lower in 1959 under heavy stocking on the rest treatment.

\section{Moisture Stress - Herbage Production Relationships}

Shrubs and pricklypear (Opuntia polyacantha Haw.) were not included in herbage production measurements. Their abundance was usually low. It is believed that their effect on both herbage production and moisture stress was minor on the sampled areas except possibly under light grazing on soil 1 .

Total Herbage Production.-Average soil moisture stress was not significantly c or r elated with total herbage production over all stocking rateXtreatmentXsoilXyear combinations ( $r=-.020$, correlation df 94). However, it was significantly correlated under light stocking in 1959 $\left(\mathrm{r}=-.530^{* *}\right.$, df 22$)$.

The relationship was close under heavy stocking on soil 2 over both years $\left(r=-.799^{*}\right.$, df 6$)$. The correlation was only slightly lower under light stocking on soil $1(\mathrm{r}=-.608$, df 6).

When stocking rates ware averaged for each treatmentXsoilXyear combination, the overall correlation of total herbage production and moisture stress was higher than before $(r=-.265$, $\mathrm{df} 46)$. Considerable variation in the relationship was apparent between soils. On overflow soil 1 , fine sandy loam soil 2 , and silty clay loam soil 3 , the correlation was negative in both years, and on soil 6 positive in both years. On silty clay loam soil 4 the correlation was high in both years, but negative in 1959 and positive in 1961. A direct or positive relationship indicates high moisture stress and high production on the same sample or low stress and low production.

Correlations of total production and moisture stress over all treatmentXstocking rateXsoil combinations were similar for 1959 and 1961.

When only the influences of range improvement treatments and years (stocking rates and soils combined) on the total herbage production-soil moisture stress relationship were considered, the correlation was very low $(r=.013$, df 6$)$. There was little difference between years, but some between treatments. The relationship of the two variables was positive on the pitted treatment and negative on the control treatment.
Production of Annual Species. Average soil moisture stress was not significantly correlated with production of annual species over all stocking rateXtreatmentXyearXsoil combinations $(\mathrm{r}=+.200$, $\mathrm{df} 94)$. No strong interactions of stocking rate with other factors were evident. A low negative correlation of average moisture stress and production of annuals under light stocking on the pitted treatment was observed.

Averaging the stocking level responses within each treatmentXsoilXyear combination did not greatly affect the overall correlation between moisture stress and production of annuals ( $r=.157$, df 46). The relation was higher on Beckton silty clay soil $4(\mathrm{r}=-.291, \mathrm{df} 6)$ than on the other soils. The correlation was negative in both years only on this soil. In 1959 the correlation on soil 6 was positive, and negative in 1961. When only the influences of treatments and years on the average soil moisture stress-production of annual species relationships were considered (stocking rates and soils averaged) the overall correlation was high ( $\mathrm{r}=.739^{*}$, df 6$)$.

Production of Perennial Species.Average soil moisture stress and production of perennials were significantly correlated whether the influences of stocking levels were included ( $\mathrm{r}=-.308^{* *}$, df 94), or omitted ( $\mathrm{r}=-.299^{* *}$, df 46). However, the relationship was higher under light stocking ( $\mathrm{r}=-.360 * *$, df 46). In contrast to those significant negative relationships the two variables were positively related under heavy stocking on soil 5 and on the pitted treatment under light stocking. The relationship between the two variables was significant over all treatments and soils in 1959 (stocking rates a verage d) $(\mathrm{r}=$ $-.436^{*}$, df 22). However, in contrast to this negative correlation the relationship was positive in 1961 on both soils 4 and 6 , and on soil 5 the relationships were positive on the pitting treatment and negative on the rest and 30 pounds of nitrogen treatments.

Over years and soils (treatments and stocking rates combined) the relationship of soil moisture tension and production of perennials was high ( $r=-.556$, df 10), but not significant. The relationship was positive on the pitted treatment in both 1959 and 1961. 


\section{Discussion}

Range improvement is shown to influence soil moisture availability. However, this effect was strongly influenced by both soils and past stocking levels. The range pitting treatment effectively increased average soil moisture availability (lower moisture stress) on two clay loam soils, but had no effect on two silty clay loam soils, a clayey soil periodically overflowed, or a fine sandy loam. This influence is apparently related to soil texture and probably inherent soil moisture infiltration rates.

Protection from grazing improved average soil moisture availability on clayey soils and reduced availability on a fine sandy loam. On the clayey soils this reaction may be due to improved infiltration rates from reduced current soil compaction, probably increased root growth, and possible recovery from past soil compaction through the soil fluffing action of freezing and thawing. On the fine sandy loam the cessation of grazing pressure may have allowed greater plant growth which increased the use of soil moisture through transpiration and possibly also evaporation.

The 30 pounds of nitrogen fertilizer was apparently effective over three years. This treatment increased moisture availability on a clay loam and a silty clay loam soil and reduce it on fine sandy loam. Apparently some combination of protection from grazing and increased plant root and top growth from the nitrogen stimulation on the clay loams caused greater soil moisture infiltration than evapotranspiration use. On the fine sandy loam soil the reverse was observed.

The influence of past stocking levels on soil moisture was apparent in the near-normal rainfall year of 1959. In the drought year of 1961, no overall stocking rate effects were evident. Also, by 1961 three of the four treatments at each site had not been grazed for three years. Sufficient recovery from past stocking may have occurred to remove the earlier difference. The overall reduced moisture stress under heavy grazing in 1959 was probably due to reduced transpiration from a reduced quantity of plant growth, lower vigor plants, and a higher composition of shallow rooted species than under light grazing, despite probably decreased infiltration from soil compaction.

The stocking level-soil interaction effects on soil moisture were primarily influenced by soil texture and slope. Soil moisture availability was lower under heavy grazing on some clayey soils. This seems due largely to reduced infiltration from compaction and sealing of the soil surface. On a sandy loam soil and on a southern exposure of a clay loam soil apparently little or no reduction in infiltration occurred. Here, plant use of soil moisture may have been reduced through the effects of heavy grazing on reducing plant growth and vigor and changing the composition toward more shallow-rooted and annual species.

A complex interaction of stocking rateXsoilXtreatmentXprecipitation effects on average soil moisture stress were observed. Each of these factors had a greater or lesser influence according to the combination of the others. The effects on soil moisture are no doubt basically related to the overall influence of the combination of either soil moisture infiltration, or evapotranspiration use of soil moisture, or some combination of these.

The relationships between average moisture stress and herbage production (total herbage, annuals only, or perennials only) were strongly affected by the various treatments and combinations. Considering all influences the best correlation was that for the perennial species and the poorest was that for total herbage production. The correlations between production of annuals and moisture stress were usually intermediate. The correlations of moisture stress with production of perennials were mostly negative indicating high production with low stress or high moisture availability. The correlations with production of annuals were usually positive indicating high production with high moisture stress.

Often sharp differences were observed in both the value and the sign of the correlation of herbage production with moisture tension between treatments, soils, stocking rates, years, and the interactions. Many of these can be traced to the influences and interactions between soil moisture infiltration properties, soil compaction from grazing, dif- ferential evapotranspiration losses, different composition of plants, and drought effects. Soil temperatures also may have influenced these relationships.

\section{Summary}

A study was established in 1957 to investigate the influence of several range improvement practices on soil moisture regimes and soil moistureherbage production relationships on native rangeland in eastern Montana. The improvement practices of rest from grazing, range pitting, and one application of nitrogen fertilizer were studied on six soils under both heavy and light stocking rates. Measurements were made during the approximately average precipitation year 1959 and the drought year 1961 .

Range pitting reduced average moisture stress (or improved moisture availability) in both years. Pitting was effective only on two clay loam soils. Rest from grazing reduced moisture stress on most clayey soils in both years, but increased it on fine sandy loam soil in 1959 . The fertilizer treatment reduced moisture stress on a clay loam and a silty clay loam soil and increased it on a fine sandy loam. There was a strong interaction of the fertilizer treatment with soils and years.

Moisture stress was lower under heavy stocking on two treatments in 1959 , but no difference was observed between stocking levels in 1961 on any $t$ reatme $n t$. Heavy stocking caused high moisture stress on most clayey soils and low stress on a sandy loam soil or on a southerly exposed clay loam.

Average soil moisture stress was significantly correlated with several components of herbage production. The best correlations were probably with production of perennial species and the poorest with total herbage production.

Many significant interaction effects were evident between the different combinations of treatments, years, soils, and stocking rates. Interaction effects were observed on both total soil moisture stress and the soil moisture stress-herbage production relationships.

\section{Literature Cited}

BAKer, John N. AND O. J. Hunt. 1961. Effects of clipping treatments and clonal differences on water requirement of grasses. Jour. Range Mangt. 14: 216-219. 
BARNES, O. K. 1952. Pitting and other treatments on native range. Wyo. Agr. Exp. Sta. Bull. 318. 23 pp.

Blatsdell, JaMes P. AND J. F. Pechanec. 1949. The effects of herbage removal at various dates on vigor of bluebunch wheatgrass and arrowleaf balsamroot. Ecology 30: 298-305.

Chambere, Dougras S. 1958. The relative removal of soil moisture by alfalfa and orchardgrass. Agron. Jour. 50: 587-589.

Duncan, D. B. 1955. Multiple range and multiple $\mathrm{F}$ tests. Biomet. 11: 1-42.

GIESEKer, L. F. 1948. Detailed soil survey of Hogback summer and Lone Pine winter range pastures, U. S. Range Livestock Experiment Station, Miles City, Montana. Mont. Agr. Exp. Sta., Unpub. Report. $32 \mathrm{pp}$.

JoHnson, W. M. 1953. Effect of grazing intensity upon vegetation and cattle gains on ponderosa pinebunchgrass ranges of the Front Range of Colorado. U.S.D.A. Cir. 929. $21 \mathrm{pp}$.

Klipple, G. E. AND D. F. Costello. 1960. Vegetation and cattle responses to different intensities of grazing on short-grass ranges of the Central Great Plains. U.S.D.A. Tech. Bull. 1216. $82 \mathrm{pp}$.

LANG, ROBERT L. 1958. Range-pitting trials in the Big Horn Mountains of Wyoming. Wyo. Agr. Exp. Sta. Bull. 357. 7 pp.

McKell, Cyrus M., Jack MaJor, AND Eugene R. Perrier. 1959. Annualrange fertilization in relation to soil moisture depletion. Jour. Range Mangt. 12: 189-193.

McKell, Cyrus M., Eugene R. PerRIER, AND G. LEDYARD STEBbINS. 1960. Responses of two subspecies of orchardgrass (Dactylis glomerata) to increasing soil moisture stress. Ecology 41: 785-790.

Rauzi, Frank and Arwine R. KuHLMAN. 1961. Water intake as affected by soil and vegetation on certain western South Dakota rangelands. Jour. Range Mangt. 14: 267-271.

Rauzi Frank and R. L. Lang. 1956. Improving shortgrass range by pitting. Wyo. Agr. Exp. Sta. Bull. 344. $11 \mathrm{pp}$.

Reed, Merton J. and R. A. Peterson. 1961. Vegetation, soil, and cattle response to grazing on the Northern Great Plains. U.S.D.A. Tech. Bull. 1252. $79 \mathrm{pp}$.

RICHARDS, S. J. AND A. W. MARSH.
1961. Irrigation based on soil suction measurements. Soil Sci. Soc. Am. Proc. 25: 65-69.

Rogler, George A. AND Russell J. LORENZ. 1957. Nitrogen fertilization of Northern Great Plains rangelands. Jour. Range Mangt. 10: $156-160$.

Smika, D. E., H. J. Hass, and G. A. ROGLER. 1960. Yield, quality, and fertilizer recovery of crested wheatgrass, bromegrass, and Russian wild-rye as influenced by fertilization. Jour. Range Mangt. 13: 243-246.

Sneva, Forrest A., Donald N. Hyder, AND C. S. COOPER. 1958. The influence of ammonium nitrate on the growth and yield of crested wheatgrass on the Oregon High Desert. Agron. Jour. 50: 40-44.

TAylor, Sterling A., D. D. Evans, AND W. D. Kemper, 1961. Evaluating soil water. Utah Agr. Exp. Sta. Bull. 426 . $67 \mathrm{pp}$.

Thomas, Gerald W. and Vernon A. YouNG. 1956. Range pitting and reseeding trials on the Texas Range Station near Barnhart, 1950-55. Tex. Agr. Exp. Sta. Prog. Rept. $1882.5 \mathrm{pp}$.

Thorne, M. D. and W. A. Raney. 1956. Soil moisture evaluation. U.S.D.A., A.R.S., ARS 41-6. 14 pp. 